\title{
Aquatic macrophytes drive sediment stoichiometry and the suspended particulate organic carbon composition of a tropical coastal lagoon
}

\author{
Macrófitas aquáticas determinam a estequiometria do sedimento e a composição do \\ carbono orgânico particulado em suspensão de uma lagoa costeira tropical
}

Cláudio Cardoso Marinho, Frederico Meirelles-Pereira, Anderson da Rocha Gripp,

Camilla de Carvalho Guimaráes, Francisco de Assis Esteves and Reinaldo Luiz Bozelli

Laboratório de Limnologia, Departamento de Ecologia, Instituto de Biologia - IB, Centro de Ciências da Saúde - CCS, Universidade Federal do Rio de Janeiro - UFRJ,

Av. Pasteur, 250, Urca, CEP 22290-240, Rio de Janeiro, RJ, Brazil

e-mail: clcamar@biologia.ufrj.br, fred@biologia.ufrj.br, dimgripp@gmail.com, camillaguimaraes.bio@gmail.com, festeves@biologia.ufrj.br, bozelli@biologia.ufrj.br

\begin{abstract}
Aim: This research aimed to evaluate (1) the influence of the aquatic macrophytes Typha domingensis Pers., Eleocharis interstincta (Vahl) Roem. \& Schult. (emergent) and Potamogeton stenostachys K. Schum. (submersed) on sediment stoichiometry and (2) the contribution of these aquatic macrophytes to organic carbon composition in different compartments of a tropical coastal lagoon (Cabiúnas Lagoon, Macaé-RJ); Methods: The concentration of carbon $(\mathrm{C})$, nitrogen $(\mathrm{N})$ and phosphorus $(\mathrm{P})$ was determined in $2-\mathrm{cm}$ intervals in the first $10 \mathrm{~cm}$ of sediment in both littoral and limnetic regions. In the littoral region, the sediment was collected in three different sites: T. domingensis, E. interstincta and P. stenostachys stands. In order to know the pathways of $\mathrm{C}$ in Cabiunas lagoon, the isotopic signature $\left(\delta^{13} \mathrm{C}\right)$ of restinga terrestrial vegetation, zooplankton, phytoplankton, macrophytes, dissolved and suspended material on water were evaluated; Results: The concentrations of $\mathrm{C}$ and $\mathrm{N}$ in the sediment of the $E$. interstincta and $T$. domingensis stands were significantly higher than in the sediment of the limnetic region. The concentration of phosphorus in the sediment colonized by T. domingensis was higher than in the limnetic region and in P. stenostachys stand. The highest molar C:P ratios were found in E. interstincta and P. stenostachys stands. The highest N:P ratios were also found in the littoral region. Carbon stable isotopic analysis $\left(\delta^{13} \mathrm{C}\right.$ signatures) showed that a majority of the particulate organic carbon (POC) in the water column had aquatic macrophyte tissues origin; Conclusions: Emergent macrophytes strongly contribute to nutrient enrichment of the sediment of Cabiúnas lagoon. In general, macrophyte detritus alters the littoral region sediment stoichiometry and quality for decomposers, by accumulating much more $\mathrm{C}$ in relation to $\mathrm{N}$ and $\mathrm{P}$ when compared to limnetic region. However, macrophytes importance isn't restricted to the sediment once they have a central role in the composition of suspended POC, thus representing an important coupling between compartments in this lagoon.
\end{abstract}

Keywords: coastal lagoon, aquatic macrophytes, organic matter, isotopic signature, stoichiometry.

Resumo: Objetivo: O objetivo desta pesquisa foi avaliar: (1) a influência das macrófitas aquáticas Typha domingensis Pers., Eleocharis interstincta (Vahl) Roem. \& Schult. (emergentes) e Potamogeton stenostachys K. Schum. (submersa), sobre a estequiometria do sedimento e (2) a contribuição desta comunidade para a composição do carbono orgânico de diferentes compartimentos de uma lagoa costeira tropical, Lagoa de Cabiúnas (Macaé, RJ); Métodos: Perfis de sedimento de $10 \mathrm{~cm}$, fracionados de $2 \mathrm{em} 2 \mathrm{~cm}$ foram coletados nas regióes litorânea e limnética para análises de nutrientes $(\mathrm{C}, \mathrm{N}$ e P). $\mathrm{Na}$ regiáo litorânea, o sedimento foi coletado em três estaçóes: bancos de T. domingensis, E. interstincta e P. stenostachys. Para avaliação da ciclagem do C na lagoa Cabiúnas foi determinada a assinatura $\delta^{13} \mathrm{C}$ de diversos compartimentos da lagoa (zoo e fitoplancton, macrófitas aquáticas e material dissolvido e suspenso na água) e da restinga (vegetação terrestre); Resultados: As concentraçôes de $\mathrm{C}$ e $\mathrm{N}$ na regiáo colonizada por $E$. interstincta e $T$. domingensis foram significativamente maiores que na região limnética. Em relação à concentração de fósforo, o sedimento colonizado pela macrófita $T$. domingensis apresentou valor significativamente maior que a regiāo limnética e a região colonizada por 
P. stenostachys. Quanto às razōes molares, a região litorânea apresentou elevadas razões C:P, principalmente nos bancos colonizados por E. interstincta e P. stenostachys. As razóes N:P também foram maiores na regiáo litorânea. As análises isotópicas $\left(\delta^{13} \mathrm{C}\right)$ mostraram que o carbono orgânico particulado na coluna d'água tem origem principalmente nos tecidos das macrófitas aquáticas; Conclusóes: As macrófitas aquáticas emersas contribuem de maneira significativa para o enriquecimento de nutrientes do sedimento da lagoa Cabiúnas. O detrito das plantas acumulado no sedimento da região litorânea, em geral, altera sua estequiometria e qualidade para os decompositores, possuindo proporcionalmente mais $\mathrm{C}$ do que $\mathrm{N}$ e $\mathrm{P}$ se comparado à região limnética. Sua importância, no entanto, não se restringe ao sedimento, pois apresentou forte influência na constituiçáo do carbono particulado suspenso na coluna d'água dessa lagoa, consistindo em importante conexão entre compartimentos desse ecossistema.

Palavras-chave: lagoa costeira, macrófitas aquáticas, matéria orgânica, assinatura isotópica, estequiometria.

\section{Introduction}

Coastal lagoons are among the most productive aquatic environments in the planet with primary production close to estuaries (Knoppers, 1994). They are usually shallow and have a high proportion of shoreline relative to area and volume, which suggests that their littoral zone is very important to ecosystem dynamics (Panosso et al., 1998). This compartment may become really important once large stands of aquatic macrophytes get established. Aquatic macrophytes comprise several different functional groups: emergent, floating-leaved, floating or submersed (Wetzel, 1983; Esteves, 1998). Functional groups strongly differ in their chemical composition and, consequently, stoichiometric ratios of biomass, which in turn influences metabolic functions in aquatic systems, such as nutrient stocking and cycling (Santos et al., 2006; Suhett, 2007). The fundamental stoichiometric differences between functional groups are based on $\mathrm{C}$ excess in relation to $\mathrm{N}$ and $\mathrm{P}$ in the structural tissues (Hessen and Anderson, 2008) of emergent macrophytes, and the ecological and evolutionary implications of these differences can be observed in decomposition experiments. In research to evaluate the uptake of dissolved oxygen in aquatic macrophytes in the first stages of decomposition in Cabiúnas Lagoon, Farjalla et al. (1999) found that the emergent macrophytes Typha domingensis Pers. and Eleocharis fistulosa Schult. (high C content) had a decomposition rate approximately 10 times slower than Potamogeton stenostachys K. Schum., a submersed macrophyte.

In an in situ study, Gonçalves Jr. et al. (2004) found that this process is 26 times faster for the floating-leaved Nymphaea ampla (Salisb.) DC. detritus than $T$. domingensis. The advances in stoichiometric theory strongly suggest that high $\mathrm{C}: \mathrm{P}$ and $\mathrm{C}: \mathrm{N}$ ratios in consumers (detritivores and herbivores) impose a nutritional constraint on growth (Hessen, 1992; Elser, 2000), such that the stoichiometric ratio in their food resource may be related to their growth rate. These findings demonstrate the importance of aquatic macrophytes at multiple time scales to the detritus food chain and their importance as a supply of dissolved (DOM) and particulate organic matter (POM), the latter being quite important to the chemical composition of the sediment.

The C:N:P ratios in the sediment has been used as an indicator of the origin of the organic matter $(\mathrm{OM})$, so they are used to determine whether the sediment is composed by autochthonous or allochthonous matter. Sedimentary organic C:N ratios are useful in distinguishing between algal and vascular land-plant origins of OM (Meyers, 1997). Hypotheses concerning the origin of organic matter in aquatic ecosystems are largely based not only on C:N:P ratios but also on the analysis of stable isotopes, such as carbon and nitrogen. Isotopes of Carbon from different sources of OM have been widely utilized to investigate consumerresource interactions and carbon and energy fluxes throughout natural food webs and ecosystems compartments (see review in Fry, 2006). C3 plants usually have $\delta^{13} \mathrm{C}$ values between $-20 \%$ and $-35 \%$, whereas C4 plants are between $-11 \%$ and $-15 \%$ o (Dawson et al., 2002), and phytoplankton in general is around $-20 \%$ (Goericke and Fry, 1994). Phytoplankton $\delta^{13} \mathrm{C}$ signatures are, however, strongly influenced by aquatic $\mathrm{CO}_{2}$ saturation (Farquhar et al., 1982). Considering that $\mathrm{CO}_{2}$ super saturation is a well-known and widespread phenomenon (Cole et al., 1994; Sobek et al., 2005; Duarte et al., 2008), these signatures could easily be more negative. 
The aim of this research was to assess the role of aquatic macrophytes as a source of organic matter to nutrient cycling in Cabiúnas Lagoon by 1) evaluating carbon, nitrogen and phosphorus concentrations and their stoichiometric ratios in the sediment from stands of the abundant species Typha domingensis, Eleocharis interstincta (Vahl) Roem. \& Schult. and Potamogeton stenostachys and at limnetic zone, and 2) evaluating the $\delta^{13} \mathrm{C}$ isotopic signatures from different sources of organic matter in order to determine possible couplings between the aquatic macrophytes of the littoral zone and pelagic food webs.

\section{Methods}

\subsection{Study area}

Cabiúnas Lagoon is located in the Restinga de Jurubatiba National Park (RJNP) at Macaé in the Northern region of Rio de Janeiro State $\left(22^{\circ} 24^{\prime} \mathrm{S}\right.$ and $\left.41^{\circ} 42^{\prime} \mathrm{W}\right)$. It is about $0.35 \mathrm{~km}^{2}$ and has a $10 \mathrm{~km}$ perimeter with a dendritic pattern (Figure 1). Cabiúnas is a dark-water, shallow system (mean depth of $2.37 \mathrm{~m}$ ) with its littoral region densely colonized by aquatic macrophytes. Of the 19 shallow lagoons located in RJNP, Cabiúnas has the greatest species richness for aquatic macrophytes assemblage (Bove and Paz, 2009).

The region has a sub-humid to humid climate with little or no water deficit, and it is mesothermic with a relatively constant temperature throughout the year. The mean annual relative humidity is approximately $83 \%$, and the mean annual temperature is $22^{\circ} \mathrm{C}$. Summer mean temperature
(January) is $25^{\circ} \mathrm{C}$, and winter mean temperature (July) is $19^{\circ} \mathrm{C}$ (INMET, 1996).

\subsection{Sampling}

The sediment samples were collected at the limnetic (site 1) and littoral regions (site 2) of Cabiúnas Lagoon (Figure 1) on September/2000. The littoral region was divided into three distinct sites: (1) a T. domingensis stand, (2) an E. interstincta stand and (3) a P. stenostachys stand. Only the superficial fraction was considered in this research $(0-10 \mathrm{~cm})$, and it was divided into 5 sub-samples at every $2 \mathrm{~cm}$. The fractions of each sample were stored in plastic bags and kept under refrigeration until laboratory analyses.

For the isotopic analysis, the samples were collected on May/2004 and July/2005. Zooplankton was collected with a $65 \mu \mathrm{m}$ mesh size net. In laboratory, it was carefully separated from detritus, washed with $10 \% \mathrm{HCl}$ and dried at $60{ }^{\circ} \mathrm{C}$ for 24 hours. Aquatic macrophytes and terrestrial vegetation were washed and dried in a similar way as zooplankton. For carbon isotope determination of phytoplankton, water samples from lagoon were collected and added $\mathrm{HgCl}$ (final concentration $-0.1 \%$ ) for biological activity interruption.

\subsection{Nutrient analysis}

To determine the concentration of carbon $(\mathrm{C})$, nitrogen $(\mathrm{N})$ and phosphorus $(\mathrm{P})$, the samples were dried at $50{ }^{\circ} \mathrm{C}$ until they reached a constant weight. The concentration of $\mathrm{N}$ was determined according to the Kjeldahl methodology (Allen et al., 1974), and the concentration of $P$ was determined according to Fassbender (1973) after acid digestion.

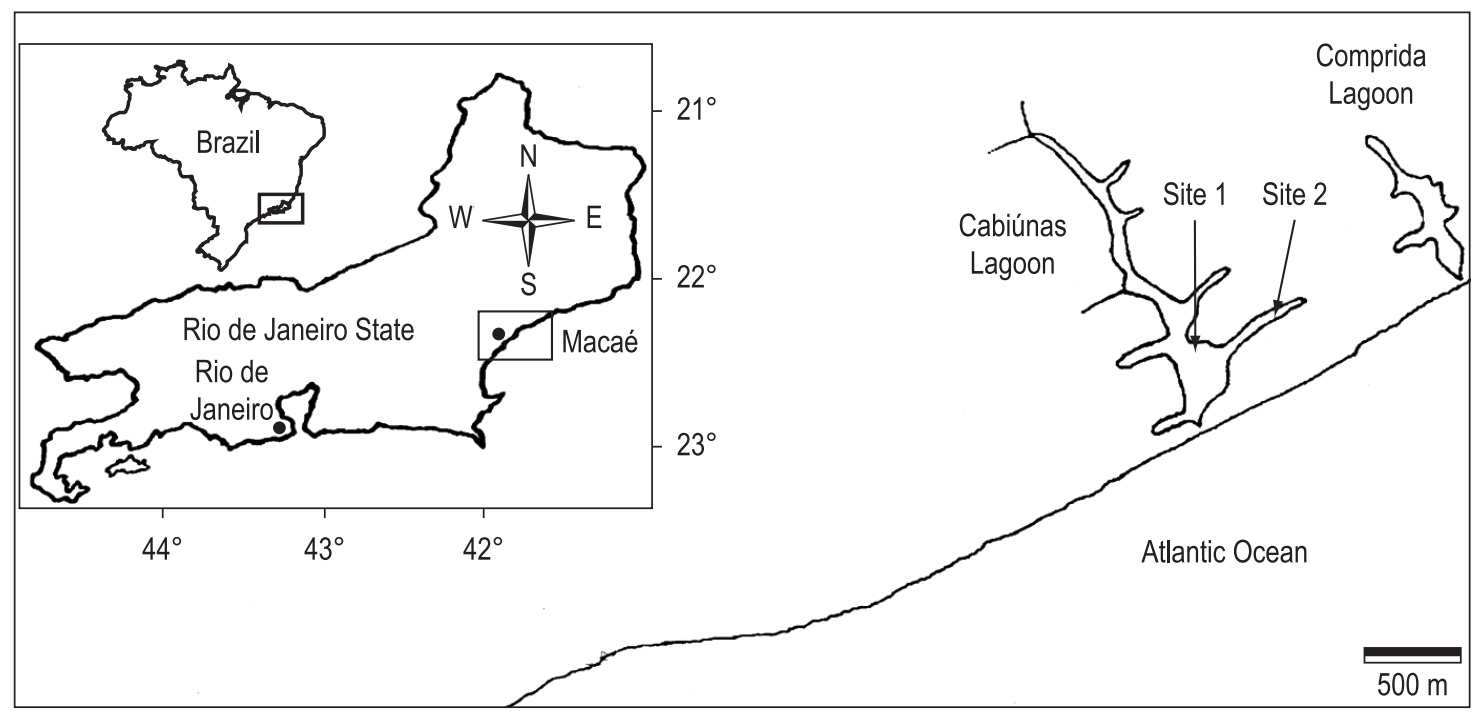

Figure 1. Location of the sampling sites in Cabiúnas Lagoon. 
The organic carbon concentration was determined by a solid sample unit of the carbon analyzer TOC5000 (Shimadzu Co., Japan).

\subsection{Carbon stable isotope analysis}

The isotopic signatures of dissolved (DOC) and particulate organic carbon (POC), zooplankton, phytoplankton, aquatic macrophytes, C4 and CAM terrestrial plants were measured using a Carlo Erba isotope ratio mass spectrometer (precision $\pm 0.2 \%$ ) following the relationship described in Peterson and Fry (1987) with Pee Dee Belemnite (PDB) as the standard reference for carbon (Equation 1):

$\delta \mathrm{X}=\left[\left(\mathrm{R}_{\text {sample }} / \mathrm{R}_{\text {standard }}\right)-1\right] \times 10^{3}$

where $\mathrm{X}$ is ${ }^{13} \mathrm{C}$, and $\mathrm{R}$ is the corresponding ratio of ${ }^{13} \mathrm{C} /{ }^{12} \mathrm{C}$.

The $\delta$ values were measured as the amounts of heavy and light isotopes in a sample. Increases in these values denote increases in the amount of the heavy isotope components. To determine the relative importance of an end-member as a source of carbon for a given compartment, we use a method modified from Forsberg et al. (1993). Phytoplankton $\delta^{13} \mathrm{C}$ estimations were performed according to Mook et al. (1974) and Farquhar et al. (1982) from the $\delta^{13} \mathrm{C}$ dissolved inorganic carbon (DIC) measurements. DOC $\delta^{13} \mathrm{C}$ was estimated from $0.22-\mu \mathrm{m}$ filtered and lyophilized water samples. The POC compartment was the compilation of three fractions of POC: POC $>0.7 \mu \mathrm{m}(\mathrm{GF} / \mathrm{F}$ filtered samples), $\mathrm{POC}<20 \mu \mathrm{m}, \mathrm{POC}>65 \mu \mathrm{m}$. The species of aquatic macrophytes collected for isotopic analysis were the following: T. domingensis, E. interstincta, P. stenostachys, N. ampla, Utricularia sp and Pistia stratiotes $\mathrm{L}$. The photosynthetic metabolism is the main factor in determining $\delta^{13} \mathrm{C}$ signatures in plants (Farquhar et al., 1982), and in the case of Cabiúnas Lagoon, virtually all macrophytes are C3 plants.

\subsection{Statistical analysis}

The mean nutrient concentrations were statistically analyzed through non-parametric ANOVA (Kruskal-Wallis test, significance level -0.05) and Dunn post-hoc tests. Nutrient correlations were determined by Pearson's linear correlation. All analyses were performed using the GraphPad Instat Program.

\section{Results}

The carbon concentration at the E. interstincta colonized site (14.02 mmolC.g $\left.{ }^{-1}\right)$ was significantly higher than at the limnetic and P. stenostachys stands (3.7 and $6.2 \mathrm{mmolC} . \mathrm{g}^{-1}$ respectively) $\mathrm{KW}$ statistic $=17.857, \mathrm{p}=0.0005 ;$ Dunn's test $\mathrm{p}<0.001$ e $\mathrm{p}<0.05$, respectively - while the carbon concentration at the $T$. domingensis stand (11.35 mmolC.g $\left.{ }^{-1}\right)$ was only significantly higher than the limnetic region (Dunn's test, $\mathrm{p}<0.05$ ). Nitrogen concentration in the sediment was significantly higher at the $T$. domingensis and $E$. interstincta stands than the limnetic region (1.21, 1.04 and $0.08 \mathrm{mmolN} . \mathrm{g}^{-1}$, respectively) KW statistic $=16.417, \mathrm{p}=0.0009$; Dunn's test $\mathrm{p}<0.05$ e $\mathrm{p}<0.01$, respectively. Only the sediment colonized by $T$. domingensis showed a higher concentration of phosphorus $\left(20.8 \mu\right.$ molP.g $\left.{ }^{-1}\right)$ than the limnetic region and the P. stenostachys stand (3.7 and $6.2 \mu$ molP.g ${ }^{-1}$, respectively) $-\mathrm{KW}$ statistic $=15.514 \mathrm{p}=0.0014$; Dunn's test $\mathrm{p}<0.01 \mathrm{e} \mathrm{p}<0.05$, respectively. Molar C:N, C:P and N:P ratios were determined as shown in Table 1. E. interstincta had the greatest C:P and, consequently, the greatest $\mathrm{C}: \mathrm{N}: \mathrm{P}$ ratio. $P$. stenostachys had the greatest $\mathrm{C}: \mathrm{N}$ ratio, and the unvegetated region had the lowest concentration values and ratios.

The Pearson correlations ( $\mathrm{r}$ ) between the C, N and $\mathrm{P}$ concentrations in the E. interstincta stand were high and positively significant (Table 1$)$ for $\mathrm{C} \times \mathrm{N}(\mathrm{r}=0.948-\mathrm{p}<0.05)$ and $\mathrm{N} \times \mathrm{P}(\mathrm{r}=0.897-$ $\mathrm{p}<0.05)$. Pearson correlations from all treatment data, analyzed together, corresponded to 0.96 , 0.78 and 0.85 for C:N, C:P and N:P, respectively, and all were significant $(\mathrm{p}<0.05)$. The $\mathrm{C}: \mathrm{N}$ ratio of DOM was $24.3(n=3)$ and of POC was 11.4 $(\mathrm{n}=3)$.

The results of the stable isotopic analysis indicate a large contribution from dominant terrestrial plants in the surroundings $\left(\delta^{13} \mathrm{C}=-13.25 \%\right.$ o \pm 0.78$)$ to the DOC compartment $\left(\delta^{13} \mathrm{C}=-18.43 \%\right.$ o \pm 0.26 ): from $-62.9 \%$ to $-78.27 \%$ o (Figure 2 ). The contribution of phytoplankton $\left(\delta^{13} \mathrm{C}=-38.72 \% \pm \pm\right.$ 1.79) to the DOC compartment was estimated to be between $-21.73 \%$ o to $-37.1 \%$ o. On the other hand, the POC composition indicates that more than $90 \%$ of this compartment was sustained by aquatic macrophyte detritus $\left(\delta^{13} \mathrm{C}=-26.6 \% 0 \pm 0.85\right)$ and aggregated periphyton $\left(\delta^{13} \mathrm{C}=-26.96 \%\right.$ o \pm 0.66$)$. Isotopic signatures estimations were performed in three different POC fractions: $<20 \mu \mathrm{m}\left(\delta^{13} \mathrm{C}=\right.$ $-28.64 \%$ o \pm 0.39$),>0.7 \mu \mathrm{m}\left(\delta^{13} \mathrm{C}=-24.24 \%\right.$ \pm $2.78)$ and $>65 \mu \mathrm{m}\left(\delta^{13} \mathrm{C}=-31.22 \%\right.$ o \pm 0.97$)$. More than $95 \%$ of carbon in zooplankton tissues was from phytoplankton origin $\left(\delta^{13} \mathrm{C}=-39.27 \%\right.$ o \pm 0.44$)$. See Figure 2 for details. 
Table 1. Carbon, nitrogen and phosphorus concentrations in Cabiúnas Lagoon sediment and the C:N, C:P and N:P molar ratios. Values in parentheses for $\mathrm{C} \times \mathrm{N}, \mathrm{C} \times \mathrm{P}$ and $\mathrm{N} \times \mathrm{P}$ correspond to Pearson's linear correlation coefficients, and values in parentheses for nutrient molar concentrations correspond to minimum and maximum values.

\begin{tabular}{|c|c|c|c|c|c|c|c|}
\hline \multirow{3}{*}{ Sites } & $\frac{\mathrm{C}}{\left(\mathrm{mmol} \cdot \mathrm{g}^{-1}\right)}$ & $\frac{\mathrm{N}}{\left(\mathrm{mmol} \cdot \mathrm{g}^{-1}\right)}$ & $\frac{P}{\left(\mu \mathrm{mol} . \mathrm{g}^{-1}\right)}$ & C-N & C-P & $\mathrm{N}-\mathrm{P}$ & \multirow{3}{*}{ C:N:P } \\
\hline & Mean \pm SD & Mean \pm SD & Mean \pm SD & C:N ratio & C:P ratio & $\mathrm{N}: \mathrm{P}$ ratio & \\
\hline & (Min-Max) & (Min-Max) & (Min-Max) & $\begin{array}{c}(\mathrm{C} \times \mathrm{N} \\
\text { correlation) }\end{array}$ & $\begin{array}{c}(\mathrm{CxP} \\
\text { correlation) }\end{array}$ & $\begin{array}{c}(\mathrm{NxP} \\
\text { correlation) }\end{array}$ & \\
\hline Limnetic region & $1.06 \pm 1.01$ & $0.08 \pm 0.04$ & $3.7 \pm 4.3$ & 13 & 286 & 22 & 286:22:01 \\
\hline & $(0.38-2.81)$ & $(0.05-0.12)$ & $(0.3-10.59)$ & $(r=0.68)$ & $(r=0.25)$ & $(r=0.08)$ & \\
\hline E. interstincta & $\begin{array}{c}14.02 \pm 0.80 \\
(13-15.2)\end{array}$ & $\begin{array}{l}1.21 \pm 0.28 \\
(0.96-1.67)\end{array}$ & $\begin{array}{c}14.1 \pm 3.7 \\
(10.3-20.2)\end{array}$ & $\begin{array}{c}11 \\
(r=0.95)^{*}\end{array}$ & $\begin{array}{c}994 \\
(r=-0.78)\end{array}$ & $\begin{array}{c}86 \\
(r=0.9)^{*}\end{array}$ & $994: 86: 1$ \\
\hline T. domingensis & $\begin{array}{c}11.35 \pm 0.60 \\
(10.7-12.2)\end{array}$ & $\begin{array}{l}1.04 \pm 0.08 \\
(0.97-1.17)\end{array}$ & $\begin{array}{l}20.8 \pm 1.5 \\
(18.9-22.4)\end{array}$ & $\begin{array}{c}10 \\
(r=-0.59)\end{array}$ & $\begin{array}{c}546 \\
(r=-0.52)\end{array}$ & $\begin{array}{c}50 \\
(r=-0.43)\end{array}$ & 546:50:01 \\
\hline P. stenostachys & $\begin{array}{l}5.12 \pm 1.33 \\
(3.55-6.63)\end{array}$ & $\begin{array}{c}0.28 \pm 0.09 \\
(0.17-0.36)\end{array}$ & $\begin{array}{l}6.2 \pm 1.7 \\
(4.6-9.1)\end{array}$ & $\begin{array}{c}18 \\
(r=-0.85)\end{array}$ & $\begin{array}{c}826 \\
(r=-0.46)\end{array}$ & $\begin{array}{c}45 \\
(r=-0.62)\end{array}$ & 826:45:01 \\
\hline
\end{tabular}

* Significant correlation.

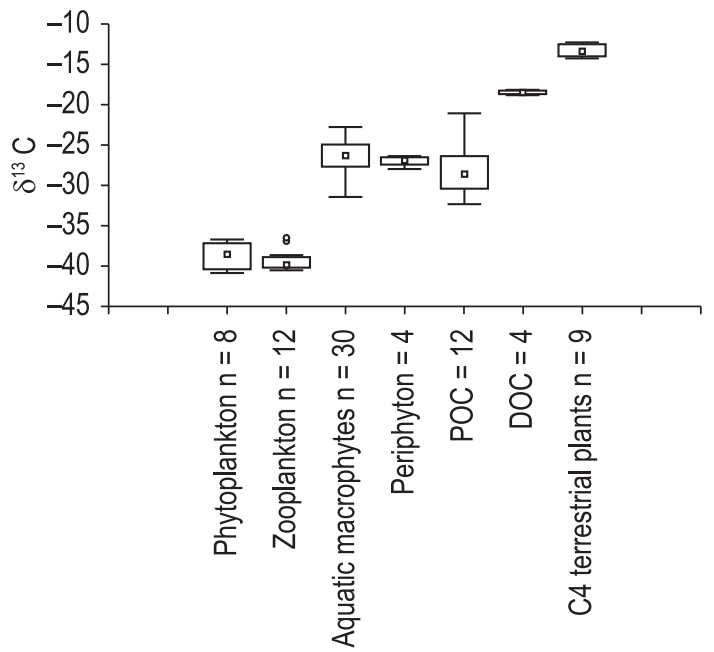

Figure 2. Carbon isotope analysis of planktonic organisms and carbon compartments in Cabiúnas Lagoon and surrounding terrestrial vegetation. The boxes represent the $25^{\text {th }}$ to $75^{\text {th }}$ percentiles, lines represent the range of data, the small squares are the medians and the circles are outliers. DOC $\delta^{13} \mathrm{C}$ was estimated from $0.22-\mu \mathrm{m}$ filtered and lyophilized water samples. POC compartment $(\mathrm{n}=12)$ is the compilation of POC $<20 \mu \mathrm{m}(\mathrm{n}=4)$, POC $>65 \mu \mathrm{m}(\mathrm{n}=4)$ and $\mathrm{POC}>0.7 \mu \mathrm{m}(\mathrm{n}=4, \mathrm{GF} / \mathrm{F}$ filtered samples).

\section{Discussion}

The deposition of OM on the sediment as detritus at sites colonized by aquatic macrophytes in Cabiúnas Lagoon indicates that a considerable amount of nutrients fixed in biomass via photosynthesis is accumulating in the littoral region and is not being exported to the pelagic zone after the death of the plants. According to Petrucio and
Faria (1998), the sediment of Cabiúnas Lagoon has a heterogeneous concentration of nutrients that distinguishes the littoral zone from the limnetic. According to Furtado and Esteves (1996), the emergent aquatic macrophytes Typha domingensis and Eleocharis fistulosa have a major role in nutrient cycling in the littoral zone of Imboassica Lagoon, which is located in the Northern region of Rio de Janeiro State. These species occur in a vast area of the littoral zone of the Imboassica Lagoon and are very important to the ecosystem metabolism because they deposit a considerable amount of detritus, store large concentrations of nutrients ( $\mathrm{N}$ and $\mathrm{P}$ ) and store a large amount of energy. The higher $\mathrm{C}$, $\mathrm{N}$ and $\mathrm{P}$ concentrations found in sediments at sites colonized by emergent macrophytes results from the high productivity rates in this compartment (Wetzel, 1983) associated with the slow debris transport to other compartments in lentic systems and their slow decomposition rates. Decomposition rates largely depend on the composition of macrophytes' tissues. Emergent macrophytes have the highest amounts of structural tissues relative to other functional groups (Farjalla et al., 1999), which results in higher $\mathrm{C}$ :nutrient ratios in detritus, as can be seen by molar ratios (Table 2) in these aquatic macrophytes and as observed in previous studies (Furtado and Esteves, 1996; Farjalla et al., 1999; Brum and Esteves, 2001; Suhett, 2007). All these factors favor the accumulation of $\mathrm{OM}$ in the sediment overtime.

Although nutrients concentration in the site colonized by the submersed macrophyte P. stenostachys were not as high as in the emergent species sites, P. Stenostachys colonization site also 
Table 2. Nutrient content, cell-wall fraction and nutrient ratios in Typha domingensis, Potamogeton stenostachys and species from the genus Eleocharis tissues.

\begin{tabular}{|c|c|c|c|c|c|c|c|c|}
\hline \multirow{2}{*}{$\begin{array}{l}\text { Macrophyte } \\
\text { stands }\end{array}$} & C & $\mathrm{N}$ & $P$ & \multirow{2}{*}{$\begin{array}{l}\text { Cell-wall } \\
\text { fraction }\end{array}$} & \multirow{2}{*}{ C:N } & \multirow{2}{*}{$C: P$} & \multirow{2}{*}{$N: P$} & \multirow{2}{*}{ Reference } \\
\hline & $(\%)$ & $(\%)$ & $(\%)$ & & & & & \\
\hline \multicolumn{9}{|l|}{ Imboassica Lagoon } \\
\hline T. domingensis & & & & & 36 & 968 & 27 & Furtado and Esteves (1996) \\
\hline E. fistulosa & & & & & 78 & 2564 & 32 & \\
\hline \multicolumn{9}{|l|}{ Cabiúnas Lagoon } \\
\hline T. domingensis & 43.72 & 0.74 & 0.04 & 62.48 & 59 & 1016 & 17 & Farjalla et al. (1999) \\
\hline E. fistulosa & 39.47 & 0.98 & 0.08 & 73.52 & 40 & 515 & 37 & \\
\hline P. stenostachys & 36.17 & 2.16 & 0.16 & 48.59 & 17 & 233 & 14 & \\
\hline E. interstincta & & & & & 28 & 962 & 35 & Brum and Esteves (2001) \\
\hline P. stenostachys & & & & & 24 & 269 & 11 & \\
\hline T. domingensis & 51.18 & 1.52 & 0.09 & 67.7 & 39 & 1471 & 37 & Suhett (2007) \\
\hline E. mutata & 47.72 & 1.68 & 0.11 & 76.84 & 33 & 1120 & 34 & \\
\hline P. stenostachys & 44.82 & 1.48 & 0.07 & 63.8 & 35 & 1653 & 47 & \\
\hline
\end{tabular}

had a high C:nutrient ratios. Farjalla et al. (1999) observed a rapid nutrient release by leaching for P. stenostachys. This leachate is much more labile than that produced by geophytes because it is richer in $\mathrm{N}$ and $\mathrm{P}$, as nitrate, ammonia and phosphate, and in organic compounds, such as carbohydrates, amino acids and organic acids. These compounds are quickly assimilated by heterotrophs such as bacteria, which then have high growth responses (Smith and Prairie, 2004; Cunha-Santino and Bianchini Jr., 2009), thereby, encouraging the recycling of organic matter released by the detritus, which results in initially high decomposition rates. As a result, a low nutritional value detritus tends to accumulate in the sediment, as can be seen by its $\mathrm{C}: \mathrm{N}$ and C:P ratios (Table 1). Some indications also come from studies in water column as Brum and Esteves (2001), that compared abundance and biomass of bacterial community attached to three macrophytes decomposing tissues (Nymphaea ampla, Potamogeton stenostachys and Eleocharis interstincta). The authors observed that the C:N:P ratios varied from 205:7:1 to $330: 15: 1$ in four days, from 168:6:1 to $269: 11: 1$ in 11 days and from 418:9:1 to 962:35:1 in 60 days for the respective macrophytes species. Suhett (2007) also found a high amount of cell-wall and $\mathrm{N}$ - and P-poorer detritus from $P$. stenostachys after leaching, which resulted in lower $\mathrm{O}_{2}$ consumption by decomposers and a low dry weight loss in water. As macrophytes have high $\mathrm{C}: \mathrm{N}: \mathrm{P}$ ratios and promote other physic-chemical changes in the sediment, it is possible to suggest that they take a long time to decompose in the sediment and, consequently, they may facilitate anaerobic processes, such as methanogenesis (Marinho et al., 2004; Fonseca et al., 2004).
The high C:P ratio (>300) in the sediment of the littoral region suggests a terrestrial influence. The C:P ratio in terrestrial plants can vary from 300 to 1300 and the C: $\mathrm{N}$ ratio from 10 to 100 . In woody tissues, these ratios are even higher: C:P > 1300 and C:N from 100 to 1000 (Ruttenberg and Goñi, 1997). However, high C:P ratios could also reflect the influence of the macrophytes because they are abundant in this region. Although stoichiometric variation in living tissues may be linked to differences in growth rates and nutritional requirements (Elser et al., 2003), detritus is composed mainly of senescent plant tissues that suffer an impoverishment in nutrients, by plant mechanisms of reallocate and retain limiting nutrients before senescence (Killingbeck, 1996). The organic matter in coastal lagoons and their drainage areas has $\mathrm{C}: \mathrm{N}$ ratios that correspond to those found in aquatic macrophytes, in the southern Baltic Sea region, as it range from 6 to 44 with a mean of 17.5 for this assemblage there (Muller and Mathesius, 1999); and this is in accordance with our results.

The strong nutrient correlations found for E. interstincta indicate that $\mathrm{N}$ and $\mathrm{P}$ concentrations may be regulated by the deposition of tissues from $E$. interstincta. This suggests a coupling between the absorption of these nutrients by decomposers or an $\mathrm{N}$ and $\mathrm{P}$ link to a C-rich structure that is resistent to decompose. Them both appear to be the case in E. interstincta stands once it have high N:P ratios, which are limiting nutrients to decomposers (Martinson et al., 2008), and have the highest cellwall fraction according to Suhett (2007). Weak correlations between $\mathrm{C}$ and $\mathrm{N}$ and a low $\mathrm{C}: \mathrm{N}$ ratio suggest an enhancement of the influence of 
inorganic $\mathrm{N}$ to the ecosystem (Datta et al., 1999); on the other hand, a high C:N ratio and weak correlations should indicate that a great amount of organic $\mathrm{C}$ is not being remineralized because decomposer stoichiometric constitution is limited by nitrogen. Furtado and Esteves (1997) observed high correlations between $\mathrm{C}, \mathrm{N}$ and pheopigments, suggesting that the main source of these elements in the sediment of a tropical coastal lagoon is the phytoplankton, aquatic macrophytes and benthonic macroalgae. Mozeto et al. (1998) studied the source of OM in the sediment of the Lobo Reservoir (São Paulo) and demonstrated the importance of the aquatic macrophytes to its composition. Their results show a high input of $\mathrm{C}$ and $\mathrm{N}$ and low input of $\mathrm{P}$ to the sediment by emergent aquatic macrophytes. The latter could be explained by the following: 1) nutrient reallocation to different parts of the plant once they are connected by rhizomes; 2) loss by leaching processes; and 3) quick assimilation by decomposers or reassimilation by the stand. The authors compared C:N ratio values from different sources and noticed that it was widely variable, which made it impossible to use these ratios to trace the origin of OM in sediments. In addition, the authors highlighted the importance of using stable isotopic analysis with $\delta^{13} \mathrm{C}$ to quantify the contribution of each source of organic carbon to sediments.

Faria and Esteves (2001) suggested that OM from aquatic macrophytes at the littoral region of coastal lagoons in northern Rio de Janeiro state decomposes predominantly at its original site, and when OM reaches the limnetic region, it is more resistant to decomposition. So, it may have some implications for the structure of Cabiúnas lagoon pelagic community, since we found POC composition to be primarily from macrophyte origin, which is also in agreement with recent decomposition experiments (Bianchini Jr. et al., 2006). The great importance of CAM and C4 terrestrial plants for DOC composition can be explained by the fact that restinga vegetation is dominated by plants with these metabolic pathways, particularly the CAM-species Clusia hilariana Schltdl., due to the their high growth performance in areas where water is scarce (Henriques et al., 1986; Araujo et al., 1998; Scarano et al., 2005). The soil of restinga is composed by sands, and the main source of OM is vegetation litter, especially from $C$. hilariana. The mechanism by which DOC is released from terrestrial litter is based on the high percolation potential of sandy soils. The high
C-litter is washed by rainwater after some initial decomposition, and the dissolved fraction is then released to sub-ground waters that connect directly to lagoon water (Suhett et al., 2007). The present results show that an important fraction of Cabiúnas DOC originates from C4/CAM-metabolism, although does not significantly enter pelagic food webs via bacteria and zooplankton.

With respect to zooplankton-C composition, our $\delta^{13} \mathrm{C}$ results were relatively surprising because several studies have shown that bacterial growth based on humic DOC may contribute significantly to zooplankton diet and growth (Karlsson et al., 2003, Daniel et al., 2005), and zooplankton may directly consume terrestrial POC (Cole et al., 2006). Stoichiometric imbalances between detritivores and herbivores in relation to primary producers are a widespread pattern in aquatic and terrestrial ecosystems (Martinson et al., 2008). These imbalances can explain the $\mathrm{N}$ and $\mathrm{P}$ depletion in sediments when compared to the composition of aquatic macrophyte tissues and the almost absolute predominance of phytoplankton C in zooplankton tissues. The slow decomposition rates of emergent macrophytes and the resulting predominance in POC as well as the prevalence of restinga $C$ in DOC are both central mechanisms to ecosystem functioning that are based on stoichiometric constraints.

The prevalence of $\mathrm{C} 4$ terrestrial-C in DOC in relation to aquatic macrophytes- $\mathrm{C}$ supports the idea that the macrophyte leachate from early stages of decomposition processes are rapidly incorporated into producers biomass (auto- or heterotrophic). Conversely, POC appears to have a high prevalence of $\mathrm{C}$ from macrophyte origins (which have $\delta^{13} \mathrm{C}$ signatures similar to periphyton). This suggests that these producers and their associated periphyton strongly influence ecosystem functioning as a whole, which represents an important coupling between littoral and pelagic zones. In the same way, there was a clear coupling pattern between restinga and Cabiúnas DOM, and this has many implications to ecological theory and conservation. This study shows a stimulating example of coupling in nutrient cycling between aquatic macrophytes, sediments and water column POC and between Cabiúnas DOC and the surrounding restinga vegetation. A tropical regime of high solar incidence along the year associated with low depths and very high perimeter/volume ratios can form an ecological scenario in which aquatic macrophytes play a central role (Wetzel, 1983). These aquatic ecosystems can 
probably frequently act as macrophyte-driven $\mathrm{C}$ sinks despite the constant $\mathrm{CO}_{2}$ super saturation in their waters.

\section{Acknowledgements}

The authors are grateful to Vinicius Farjalla, Adriana Rocha and two anonymous reviewers for essential comments on the manuscript. We also thank CAPES and CNPq for financial support.

\section{References}

ALLEN, SE., GRIMSHAW, HM., PARKINSON, JA. and QUARMBY, C. 1974. Chemical analysis of ecological material. Oxford: Blackwell Scientific Publications. 565 p.

ARAUJO, DSD., SCARANO, FR., SÁ, CFC., KURTZ, BC., ZALUAR, HLT., MONTEZUMA, RCM. and OLIVEIRA, RC. 1998. Comunidades vegetais do Parque Nacional da Restinga de Jurubatiba. In ESTEVES, FA., ed. Ecologia das Lagoas Costeiras do Parque Nacional da Restinga de Jurubatiba e do Município de Macaé (RJ). Rio de Janeiro: NUPEMUFRJ. p. 39-62.

BIANCHINI Jr., I., PERET, AM. and CUNHASANTINO, MB. 2006. A mesocosm study of aerobic mineralization of seven aquatic macrophytes. Aquatic Botany, vol. 85, p. 163-167.

BOVE, CP. and PAZ, J. 2009. Guia de campo das plantas aquáticas do Parque Nacional da Restinga de Jurubatiba, Rio de Janeiro - Brasil. Rio de Janeiro: Museu Nacional. 176 p.

BRUM, PR. and ESTEVES, FA. 2001. Changes in abundance and biomass of the attached bacterial community throughout the decomposition of three species of aquatic macrophytes In: FARIA, BM., FARJALLA, VF. and ESTEVES, FA., ed. Aquatic Microbial Ecology in Brazil. Rio de Janeiro: PPGEUFRJ. p. 77-96. Oecologia Brasiliensis, vol. 9.

COLE, JJ., CARACO, NF., KLING, GW. and KRATZ, TK. 1994. Carbon dioxide supersaturation in the surface waters of lakes. Science, vol. 265, p. $1568-1570$.

COLE, JJ., CARPENTER, SR., PACE, ML., VAN DE BOGERT, MC., KITCHELL, JF. and HODGSON, JR. 2006. Differential support of lake food webs by three types of terrestrial organic carbon. Ecology Letters, vol. 9, p. 558-568.

CUNHA-SANTINO, MB. and BIANCHINI Jr., I. 2009. Humificação e mineralização de macrófitas aquáticas: uma revisão sobre esses processos. Oecologia Brasiliensis, vol. 13, no. 4, p. 665-675.

DANIEL, C., GUTSEIT, K., ANESIO, AM. and GRANÉLI, W. 2005. Microbial food webs in the dark: independence of lake plankton from recent algal production. Aquatic Microbial Ecology, vol. 38, p. 113-123.

DATTA, DK., GUPTA, LP. and SUBRAMANIAM, V. 1999. Distribution of C, N and P in the sediments of the Ganges-Brahmaputra-Meghna river system in the Bengal basin. Organic Geochemistry, vol. 30, p. 75-82.

DAWSON, TE., MAMBELLI, S., PLAMBOECK, AH., TEMPLER, PH. and TU, KP. 2002. Stable isotopes in plant ecology. Annual Review of Ecology and Systematics, vol. 33, p. 507-559.

DUARTE, CM., PRAIRIE, YT., MONTES, C., COLE, JJ., STRIEGL, R., MELACK, J. and DOWNING, JA. 2008. CO2 emissions from saline lakes: a global estimate of a surprisingly large flux. Journal of Geophysical Research-Biogeosciences, vol. 113, no. 4.

ELSER, JJ. 2000. Stoichiometric analysis of pelagic ecosystems: the biogeochemistry of planktonic food webs. In SALA, OE., JACKSON, RB., MOONEY, HA. and HOWARTH, R., ed. Methods in Ecosystem Science. Berlin: Springer-Verlag. p. 389-406.

ELSER, JJ., ACHARYA, K., KYLE, M., COTNER, J., MAKINO, W., MARKOW, T., WATTS, T., HOBBIE, S., FAGAN, W., SCHADE, J., HOOD, J. and STERNER, RW. 2003. Growth ratestoichiometry couplings in diverse biota. Ecology Letters, vol. 6, p. 936-943.

ESTEVES, FA. 1998. Fundamentos de Limnolgia. 2. ed. Rio de Janeiro: Interciência. 602 p.

FARIA, BM. and ESTEVES, FA. 2001. Dissolved organic carbon in two Brazilian coastal lagoons: sources and utilization for heterotrophic bacteria. Oecologia Brasiliensis, vol. 9, p. 57-64.

FARJALLA, VF., AMADO, AM., SUHETT, AL. and MEIRELLES-PEREIRA, F. 2009. DOC removal paradigms in highly humic aquatic ecosystems. Environmental Science \& Pollution Research, vol. 16, p. 531-538.

FARJALLA, VF., MARINHO, CC. and ESTEVES, FA. 1999. Uptake of oxygen in the initial stages of decomposition of aquatic macrophytes and detritus from terrestrial vegetation in a tropical coastal Lagoon. Acta Limnologica Brasiliensia, vol. 11, no. 2, p. 185-193.

FARQUHAR, GD., O'LEARY, MH. and BERRY, JA. 1982. On the relationship between carbon isotope discrimination and the intercellular carbon dioxide concentration in leaves. Australian Journal of Plant Physiology, vol. 9, p. 121-137.

FASSBENDER, HW. 1973. Simulate P-Bestinmung in N-Kjeldahl Ausfschlub von Bodenproben. Die Phosphörsäure, vol. 30, p. 44-53.

FONSECA, ALS., MINELLO, M., MARINHO, CC. and ESTEVES, FA. 2004. Methane concentration in water column and in pore water of a coastal lagoon (Cabiúnas lagoon, Macaé, RJ, Brazil). Brazilian 
Archives of Biology and Technology, vol. 47, no. 2, p. 301-308.

FORSBERG, BR., ARAÚJO-LIMA, CARM., MARTINELLI, LA., VICTORIA, RL. and BONASSI, JA. 1993. Autotrophic carbon sources for fish of the Central Amazon. Ecology, vol. 74, p. 643-652.

FRY, B. 2006. Stable Isotope Ecology. New York: Springer.

FURTADO, LS. and ESTEVES, FA. 1996. Organic compounds, nutrients and energy of two tropical aquatic macrophytes. Brazilian Archives of Biology and Technology, vol. 39, no. 4, p. 923-931.

FURTADO, LS. and ESTEVES, FA. 1997. Nutritional value of biomass and detritus of Typha domingensis Pers.(Typhaceae). Revista Brasileira de Biologia, vol. 57, no. 2, p. 317-321.

GOERICKE, R. and FRY, B. 1994. Variations of Marine plancton $\delta^{13} \mathrm{C}$ with latitude, temperature and dissolved $\mathrm{CO}_{2}$ in the world ocean. Global Biogeochemistry Cycles, vol. 8, p. 85-90.

GONÇALVES Jr., JF., SANTOS, AM. and ESTEVES, FA. 2004. The influence of the chemical composition of Typha domingensis and Nymphaea ampla detritus on invertebrate colonization during decomposition in a Brazilian coastal lagoon. Hydrobiologia, vol. 527, p. 125-137.

HENRIQUES, RPB., ARAUJO, DSD. and HAY, JD. 1986. Descrição e classificação dos tipos de vegetação da restinga de Carapebus, Rio de Janeiro. Revista Brasileira de Botânica, vol. 9, p. 173-189.

HESSEN, DO. 1992. Nutrient element limitation of zooplankton production. The American Naturalist, vol. 140 , p. $799-814$.

HESSEN, DO. and ANDERSON, TR. 2008. Excess carbon in aquatic organisms and ecosystems: Physiological, ecological and evolutionary implications. Limnology and Oceanography, vol. 53, no. 4, p. 1685-1696.

Instituto Nacional de Meteorologia - INMET. 1996. Relatórios do Instituto Nacional de Meteorologia. Rio de Janeiro: INMET.

KARLSSON, J., JONSSON, A., MEILI, M. and JANSSON, M. 2003. Control of zooplankton dependence on allochthonous organic carbon in humic and clearwater lakes in northern Sweden. Limnology and Oceanography, vol. 482, p. 269-276.

KILLINGBECK, KT. 1996. Nutrients in senesced leaves: keys to the search for potential resorption and resorption proficiency. Ecology, vol. 77, p. 1716-1727.

KNOPPERS, B. 1994. Aquatic primary production in coastal lagoons. In KJERFVE, B., ed. Coastal lagoon processes. Elsevier. p. 243-286. Oceanography Series, vol. 60 .
MARINHO, CC., FONSECA, ALS., MINELLO, M. and ESTEVES, FA. 2004. Resultados e Perspectivas sobre o Estudo do Metano nas Lagoas Costeiras da Restinga de Jurubatiba e na Lagoa Imboassica na Região Norte do Estado do Rio de Janeiro. In: ROCHA, CFD., ESTEVES, F. and SCARANO, FR., ed. Pesquisas de longa duração na Restinga de Jurubatiba: Ecologia, História natural e conservação. São Carlos: RiMa. p. 273-294.

MARTINSON, HM., SCHNEIDER, K., GILBERT, J., HINES, JE., HAMBA, PA. and FAGAN, WF. 2008. Detritivory: stoichiometry of a neglected trophic level. Ecological Research, vol. 23, p. 487-491.

MEYERS, PA. 1997. Organic geochemical proxies of paleoceanographic, paleolimnologic and paleoclimatic processes. Organic Geochemistry, vol. 27, p. 213-250.

MOOK, WG., BOMMERSON, JC. and STAVERMAN, WH. 1974. Carbon isotope fractionations between dissolved bicarbonate and gaseous carbon dioxide. Earth and Planetary Science Letters, vol. 22, p. 169-176.

MOZETO, AA., NOGUEIRA, FMB. and ESTEVES, FA. 1998. Caracterização das fontes de matéria orgânica dos sedimentos da Represa do Lobo (SP) através do uso da composição de Carbono-13. Acta Limnologica Brasilensia, vol. 12, p. 943-963.

MULLER, A. and MATHESIUS, U. 1999. The palaeoenvironments of coastal lagoons in the southern Baltic Sea, I. The application of sedimentary Corg/N ratios as source indicators of organic matter. Palaeogeography, Palaeoclimate, Palaeoecology, vol. 145, p. 1-16.

PANOSSO, RF., ATTAYDE, JL. and MUEHE, D. 1998. Morfometria das Lagoas Imboassica, Cabiúnas, Comprida e Carapebus: Implicaçôes Para seu Funcionamento e Manejo. In ESTEVES, FA., ed. Ecologia das Lagoas Costeiras do Parque Nacional da Restinga de Jurubatiba e do Município de Macaé (RJ). Rio de Janeiro: NUPEM-UFRJ. p. 91-105.

PETERSON, BJ. and FRY, B. 1987. Stable isotopes in ecosystem studies. Annual Review of Ecology and Systematics, vol. 18, p. 293-320.

PETRUCIO, MM. and FARIA, BM. 1998. Concentraçóes de carbono orgânico, nitrogênio total e fósforo disponível no sedimento das lagoas Cabiúnas e Comprida. In ESTEVES, FA., ed. Ecologia das lagoas costeiras do Parque Nacional da Restinga de Jurubatiba e do Município de Macaé (RJ). Rio de Janeiro: NUPEMUFRJ. p. 135-136.

RUTTENBERG, KC. and GONI, MA. 1997. Phosphorus Distribution, C:N:P Ratios, and $\delta^{13} \mathrm{C}$ in Arctic, Temperate and Tropical Coastal Sediments: Tolls for Characterizing Bulk Sedimentary Organic Matter. Marine Geology, vol. 139, p. 123-145. 
SANTOS, AM., AMADO, AM., MINELLO, M., FARJALLA, VF. and ESTEVES, FA. 2006. Effects of the Sand Bar Breaching on Typha domingensis (Pers.) in a Tropical Coastal Lagoon. Hydrobiologia, vol. 556, p. 61-68.

SCARANO, FR., DUARTE, HM., FRANCO, AC., GEBLER, A., MATTOS, EA., NAHM, M., RENNENBERG, H., ZALUAR, HTL. and LÜTTGE, U. 2005. Ecophysiology of selected tree species in different plant communities at the periphery of the Atlantic Forest of SE-Brazil I. Behaviour of three different species of Clusia in an array of plant communities. Trees, Structure and Function, vol. 19, no. 5, p. 523-530.

SMITH, EM. and PRAIRIE, YT. 2004. Bacterial metabolism and growth efficiency in lakes: The importance of phosphorus availability. Limnology and Oceanography, vol. 49, p. 137-147.
SOBEK, S., TRANVIK, LJ. and COLE, JJ. 2005. Temperature independence of carbon dioxide supersaturation in global lakes. Global Biogeochemistry, vol. 19 , no. 2.

SUHETT, AL. 2007. Efeitos da Diversidade de Macrófitas sobre sua Decomposição. Rio de Janeiro: UFRJ. [Dissertação de Mestrado em Ecologia].

SUHETT, AL., AMADO, AM., ENRICH-PRAST, A., ESTEVES, FA. and FARJALLA, VF. 2007. Seasonal changes of dissolved organic carbon photo-oxidation rates in a tropical humic lagoon: the role of rainfall as a major regulator. Canadian Journal of Fisheries and Aquatic Sciences, vol. 64, no. 9, p. 1266-127

WETZEL, RG. 1983. Limnology. $2^{\text {nd }}$ ed. Philadelphia: Sounders College. 860 p.

Received: 16 May 2010 Accepted: 05 October 2010 